\title{
Does Iron Chelation by Melanin Explain the Ethnic Link with Covid-19 Fatality?
}

\author{
PA Riley ${ }^{1 *}$ and TG Truscott ${ }^{2}$ \\ ${ }^{1}$ Totteridge Institute for Advanced Studies, The Grange, Grange Avenue, London, UK \\ ${ }^{2}$ School of Chemical and Physical Sciences, Keele University, Staffordshire, UK
}

*Corresponding author: PA Riley, Totteridge Institute for Advanced Studies, The Grange, Grange Avenue, London, N20 8AB, UK

\begin{tabular}{|c|c|}
\hline ARTICLE INFO & ABSTRACT \\
\hline Received: 蔧 October 20, 2020 & Citation: PA Riley, TG Truscott. Does Iron Chelation by Melanin Explain the Ethnic Link \\
\hline Published: 㗀 November 11, 2020 & with Covid-19 Fatality?. Biomed J Sci \& Tech Res 31(5)-2020. BJSTR. MS.ID.005166. \\
\hline
\end{tabular}

\section{Introduction}

There has been a great deal of comment concerning the apparent ethnic differences in the clinical outcome of Corvid-19 infection and many possible factors including socio-economic influences and vitamin D levels have been discussed. However, a clear association has been observed between the death rate from Covid-19 infection and skin types IV to VI (brown to black) [1,2]. This correlation with the degree of epidermal pigmentation suggests that melanin is in some way implicated.

\section{Epidermal Melanin}

Melanin is a polymeric pigment derived from the oxidation of tyrosine, a process that takes place in specialised pigmentgenerating cells (melanocytes) where it is deposited in pigment granules (melanosomes) and transferred to surrounding cells. In the case of skin pigmentation, the melanin granules are continuously synthesised by epidermal melanocytes and transferred to the adjacent epidermal cells. The degree of skin pigmentation is a function of several genetically determined factors including the rate of melanin synthesis, the size of the melanin granules and the number of melanin granules transferred to epidermal cells [3].

\section{Properties of Melanin}

An important property of melanin is its strong light absorbance, and epidermal pigment takes part in several significant photoprotective processes such as scavenging of both oxidising and reducing free radicals [4].

Another notable property of melanin is its powerful metalchelating characteristic [5-9]. As the epidermal cell population is constantly turning over, being lost by surface desquamation [10], there is continuous replacement of epidermal pigment. Thus, the turnover of epidermal melanin provides an excretory pathway for metals, and it has been suggested that the ability of melanin to bind heavy metals and sequester them within a segregated compartment that is ultimately shed from the skin surface may act as a detoxification mechanism with significance to hominid evolution [11,12]. Many metals have been shown to be bound to melanin, including zinc and copper [13,14], and their transepidermal loss may be relevant, since zinc is known to have a role in anti-viral action [15] so that its melanin-linked elimination may be significant.

\section{Iron Chelation by Melanin}

However, we propose that a more important candidate in relation to the vulnerability to Covid-19 infection is iron because of the marked affinity of eumelanin for iron. For example, Liu, et al. [16] recorded a 400-fold increase in iron uptake by Sepia melanin granules exposed to a solution of ferric chloride and $\mathrm{Fe}++$ is known to be even more strongly bound to melanin. Also, as anticipated, it has been shown that the amount of iron in the epidermis is influenced by the degree of melanisation. For example, it has been shown that three times as much iron was present in sun-exposed compared to sun-shielded skin [17].

\section{Melanin-Bound Iron Excretion and Iron Homeostasis}

An investigation of iron metabolism has demonstrated that trans-epidermal iron elimination accounts for $20-25 \%$ of the daily iron loss [18]. Therefore, the degree of epidermal pigmentation 
constitutes a fundamental regulatory factor in iron homeostasis by influencing the extent of trans-epidermal iron loss.

\section{Susceptibility to Hypoxia}

Thus, our proposal is that due to melanin-bound iron loss, raised levels of epidermal pigmentation increase the susceptibility to lower homeostatic iron levels. As a result of this, depending on other relevant factors such as dietary iron intake, skin type IV-VI individuals incur an increased risk of iron-deficiency anaemia and this renders them more vulnerable to the hypoxic conditions caused by the respiratory effects of Covid-19 infection [19,20].

\section{Acknowledgement}

We thank Dr. Ruth Edge for helpful discussions.

\section{References}

1. Khunti K, Platt L, Routen A, Abbasi K (2020) Ethnicity and Covid-19. BMJ 369: 2282.

2. Pareek M, Bangash MN, Pareek N, Pan DS, Sze S, et al. (2020) Ethnicity and COVID-19: an urgent public health research priority. Lancet 395: (10234): 1421-1422.

3. Hearing VJ (2011) Genetics of melanosome structure and function. In Melanins and Melanosomes (Eds. J. Borovansky and P.A.Riley), WileyBlackwell: Weinheim pp. 323-341.

4. Rozanowska M, Sarna T, Land EJ, Truscott TG (1999) Free radical scavenging properties of melanin interaction of eu- and pheo-melanin models with reducing and oxidising radicals. Free Rad Biol Med 26(5-6): 518-525.

5. Larson B, Tjalve H (1978) Studies on the melanin affinity of metal ions. Acta Physiol Scand 104(4): 479-484.

6. Hong L, Liu Y, Simon J (2007) Binding of metal ions to melanin and their effects on aerobic reactivity. Photochem Photobiol 80(3): 477-411.

7. Hong L, Simon JD (2007) Current understanding of the binding sites, capacity, affinity and biological significance of metals in melanin. J Phys Chem B 111(28): 7938-7947.

\section{ISSN: 2574-1241}

DOI: $10.26717 /$ BJSTR.2020.31.005166

PA Riley. Biomed J Sci \& Tech Res

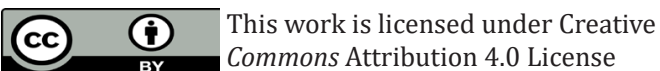

Submission Link: https://biomedres.us/submit-manuscript.php
8. Bogacz A, Buszmann E, Wilczok T (1983) Competition between metal ions for DOPA melanin. Studia Biophysica 132: 189-195.

9. Sarna T, Swartz HA (2006) The Physical Properties of Melanin. In: The Pigmentary System Physiology and Pathophysiology (Eds. JJ Nordlund, RE Boissy, VJ Hearing, RA King, W. Oetting and JP Ortonne), Blackwell Publishing Ltd.: Oxford. $2^{\text {nd }}$ edn. pp. 311-341.

10. Weinstein GD, McCullough JL, Ross P (1984) Cell proliferation in normal epidermis. J Invest Derm 82(6): 623-628.

11. Riley PA (1997) Epidermal melanin: sunscreen or waste disposal? Biologist 44: 408-411.

12. Riley PA (2010) The evolution of epidermal pigmentation: A speculative comment. Nederlands Tijsch Derm Vener 20(5): 277-278.

13. Horcicko J, Borovansky J, Duchon J, Prochazkova B (1973) Distribution of zinc and copper in pigment tissues. Hoppe-Seyler's Z Physiol Chem 354: 203-204

14. Szpoganicz B, Gidanian S, Kong P, Farmer P (2002) Metal binding by melanins: Studies of colloidal dihydroxyindole-melanin, and its complexation by $\mathrm{Cu}(\mathrm{II})$ and Z(II) ions. J Inorg Biochem 89(1-2): 45-53.

15. Kumar A, Kubota Y, Chernov M, Kasuya H (2020) Potential role of zinc supplementation in prophylaxis and treatment of COVID-19. Med Hypotheses 144: 109848.

16. Liu Y, Hong L, Kempf VE, Wakamatsu K, Ito S, et al. (2004) Ion exchange and adsorption of Fe(III) by Sepia Melanin. Pigment Cell Res 17(3): 262269.

17. Bissett DL, McBride JF (1992) Iron content of human epidermis from sun-exposed and non-exposed body sites. J Soc Cosmet Chem 43: 215217.

18. Millstone LM, Hu RH, Dziura JD, Zhou J (2012) Impact of epidermal desquamation on tissue stores of iron. Dermatol Sci 67(1): 9-14.

19. Zhao K, Huang J, Dai D, Feng Y, Liu L, et al. (2020) Serum Iron Level as a Potential Predictor of Coronavirus Disease 2019 Severity and Mortality: A Retrospective Study. Open Forum: Infectious Diseases 7(7): 250.

20. Taneri PE, Gomez-Ochoaz SA, Llanaj E, Raguindin PF, Rojas LZ, et al. (2020) Anemia and iron metabolism in COVID-19: Systematic Review and Meta-analysis. medRxiv preprint.

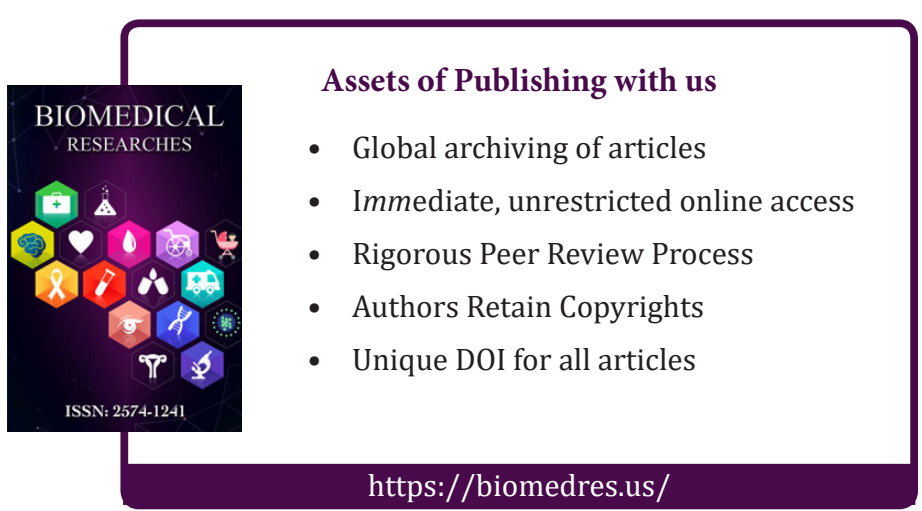

